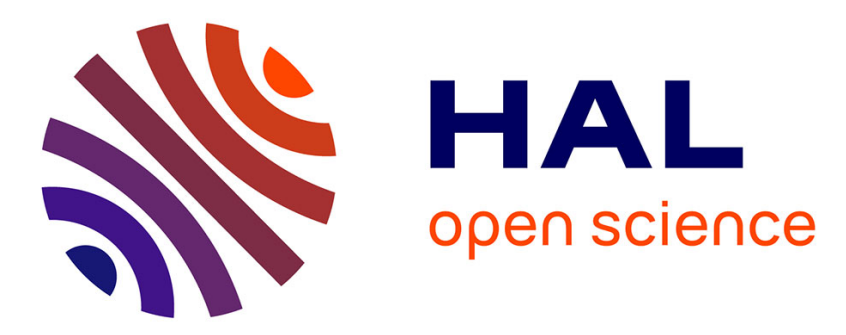

\title{
Loading policies in cellular manufacturing systems with remainder cell
}

\author{
Paolo Renna, Michele Ambrico
}

\section{To cite this version:}

Paolo Renna, Michele Ambrico. Loading policies in cellular manufacturing systems with remainder cell. International Journal of Computer Integrated Manufacturing, 2011, 24 (07), pp.661-675. 10.1080/0951192X.2011.570791 . hal-00712364

\section{HAL Id: hal-00712364 \\ https://hal.science/hal-00712364}

Submitted on 27 Jun 2012

HAL is a multi-disciplinary open access archive for the deposit and dissemination of scientific research documents, whether they are published or not. The documents may come from teaching and research institutions in France or abroad, or from public or private research centers.
L'archive ouverte pluridisciplinaire HAL, est destinée au dépôt et à la diffusion de documents scientifiques de niveau recherche, publiés ou non, émanant des établissements d'enseignement et de recherche français ou étrangers, des laboratoires publics ou privés. 


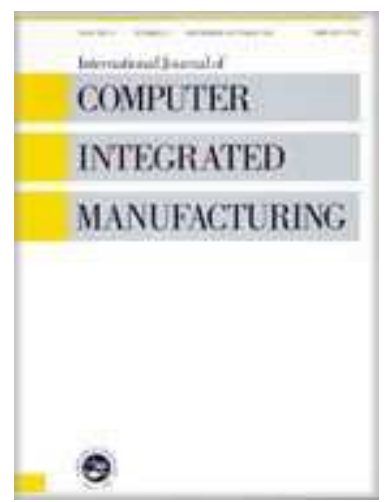

\section{Loading policies in cellular manufacturing systems with remainder cell}

\begin{tabular}{|c|c|}
\hline Journal: & International Journal of Computer Integrated Manufacturing \\
\hline Manuscript ID: & TCIM-2010-IJCIM-0081.R1 \\
\hline Manuscript Type: & Original Manuscript \\
\hline $\begin{array}{r}\text { Date Submitted by the } \\
\text { Author: }\end{array}$ & 10-Dec-2010 \\
\hline Complete List of Authors: & $\begin{array}{l}\text { Renna, Paolo; University of Basilicata, DIFA } \\
\text { Ambrico, Michele; University of Basilicata, DIFA }\end{array}$ \\
\hline Keywords: & $\begin{array}{l}\text { CELLULAR MANUFACTURE, SCHEDULING, DYNAMIC } \\
\text { ENVIRONMENTS, DISCRETE EVENT SIMULATION }\end{array}$ \\
\hline Keywords (user): & remainder cell \\
\hline
\end{tabular}

\section{SCHOLARONE ${ }^{\mathrm{m}}$ Manuscripts}




\title{
Loadingpolicies in cellular manufacturing systems with remainder cell
}

\author{
Paolo Renna, Ph.D.( Correspondig author) \\ Assistant Professor in Manufacturing Technology and Production systems \\ Universityof Basilicata - DIFA - Via dell'Ateneo Lucano,10 85100 Potenza -Italy \\ e-mail: paolo.renna@unibas.it \\ Tel. +39 0971205143 \\ Fax +390971205160 \\ Michele Ambrico \\ Ph.D. Student in Manufacturing Technology and Production systems \\ Universityof Basilicata - DIFA - Via dell'Ateneo Lucano,10 85100 Potenza -Italy \\ e-mail: michele.ambrico@unibas.it \\ Tel. +390971205050 \\ Fax +390971205160
}

Cellular manufacturing systems are used when both production volume and product variety are at medium level. The fluctuations of volume and mix can reduce drastically the performance of classical cellular manufacturing systems. Therefore, several configurations have been proposed in literature as virtual manufacturing cells, fractal cells and remainder cells. This paper investigates the cell loading approaches in a manufacturing system composed of dedicated cells and a remainder cell. The remainder cell consists of machines able to manufacture all part families. The loading decision concerns the allocation of the parts to the remainder cell, instead of the dedicated cell. A simulation environment based on Rockwell ARENA ${ }^{\circledast}$ has been developed to test the proposed approaches. The performance measures are evaluated in a very dynamic environment characterized by volume oscillations, mix fluctuations and machine failures. A classical cellular manufacturing system is used as a benchmark for the performance measures analyzed. The simulation results show that the proposed policies lead to better performance when market fluctuations occur.

Keywords Cellular manufacture, scheduling, dynamic environments, discrete event simulation, remainder cell 


\title{
Loadingpolicies in cellular manufacturing systems with remainder cell
}

\begin{abstract}
Cellular manufacturing systems are used when both production volume and product variety are at medium level. The fluctuations of volume and mix can reduce drastically the performance of classical cellular manufacturing systems. Therefore, several configurations have been proposed in literature as virtual manufacturing cells, fractal cells and remainder cells. This paper investigates the cell loading approaches in a manufacturing system composed ofdedicated cells and a remainder cell.The remainder cell consists of machines able to manufacture all part families. The loading decision concerns the allocation of the parts to the remainder cell, instead of the dedicated cell. A simulation environment based on Rockwell ARENA ${ }^{\circledast}$ has been developed to test the proposed approaches. The performance measures are evaluated ina very dynamic environment characterized byvolume oscillations, mix fluctuations and machine failures. A classical cellular manufacturing system is used as a benchmark for the performance measures analyzed. The simulation results show that the proposed policies lead to better performance when market fluctuations occur.
\end{abstract}

Keywords: cellular manufacture, scheduling, dynamic environments, discrete event simulation, remainder cell

\section{Introduction and motivations}

Cellular manufacturing systems (CMSs)are the more appropriate configuration to obtain the better performance when the production variety and volume are at medium level. The CMSs are characterized by the following benefits: simplification and reduction in material handling, decreasing the work in process, reduction in set-up time, increment in flexibility, better production control, and shorter lead time (Askinand Estrada, 1999). These benefits can be obtained when the demand volume and mix are rather constant respect to the design data of the manufacturing cells.In order to remain efficient, the CMSs need to be reconfigured when the manufacturing conditions change(Chen, 1998). Nowadays, competition is characterized by short life-cycle of the products, introduction of new products, demand and mix fluctuations. These issues lead to reduce drastically the "life cycle" of a CMS configuration with numerous re-configuration activities. Each reconfiguration activity causes costs of re-design of manufacturing cells and set-up times that reduce the availability of the manufacturing system. Tompkins et al. (2003)

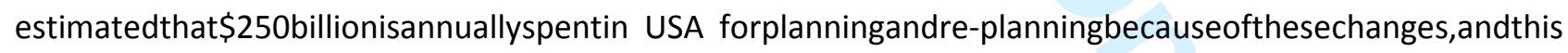
huge costcanbereducedby10-30\%viaeffectiveplanning.In literature, several alternatives were proposed as: virtual manufacturing cells (McLeanetal., 1982), fractal cells,(Vektadari et al., 1997; Monteruil et al., 1999), holonic cells (Montreuil et al., 1993) and remainder cells introduction in the design of CMSs (Maddisetty, 2005). The focus of this paper is on the operation management of remainder cells in a CMS environment. The aim of the research concerns the development and analysis of loading approaches to integrate the remainder cell within the classical CMS. In particular, there are proposed three loading policies to decide when a generic part will be loaded in remainder cell instead of the manufacturing cell designed for the family of the part. A simulation environment has been developed in order to test the proposed policies when market fluctuations occur in terms of product mix and demand. Therefore, the benefits of the proposed approaches are tested in several dynamic conditions compared with a classical cellular manufacturing configuration. The rest of the paper is structured as follows: Section 2 provides an overview of the literature of remainder cells in CMSs, while in Section 3 the problem context is formulated. The loading approaches proposed are described in Section 4. Section 5 presents the simulation 
environment and the case study. The numerical results are discussed in Section 6, while the conclusions and future research paths are drawn in Section 7.

\section{Literature review}

Several authors addressed the problem of adaptability of CMSs when some factors change such as: uncertain in demand, mix fluctuations and new product introduction.

Mak and Wong (2000) investigated the problem of resource allocation in a context of multiple production lines, each line is able to manufacture a range of products. A genetic algorithm was developed for product grouping and allocates the group to a production line. The uncertain considered is the volume of product and the demand.

Saad et al.(2002) discussed a multiple objective simulation optimization model for loading flexible cells. The approach developed is composed by three main modules: generic process planning module, a multiobjective algorithm based on tabu search method to generate and evaluate candidate part to cell scenarios; the performancemeasures are determined by simulation module.

Huang et al. (2003)developed an algorithm to optimize decision on capacity exchange between rush orders and prescheduled orders. Therefore, it can be considered as a mix production variation on the CMS.

Maddisetty (2005) integrated the design and operational control of CMS when the product demand is stochastic. The configurations investigated are: classical, shared and remainder cells. The performance measures evaluated are the work in process and average flow time.

Süer et al. (2009) proposed a new layered cellular manufacturing system to form dedicated, shared and remainder cells to deal with the probabilistic demand, and its performance is compared with the classical cellular manufacturing system. The performance of work in process and average flow time are betterthan the classical cellular system when high demand fluctuation was observed.

Safei et al. (2007) proposed a fuzzy programming based approach to design a cellular manufacturing system under dynamic and uncertain conditions. The dynamic conditions are characterized by multi-period planning horizon, in which the product mix and demand in each period can be different.

Bhandwale andKesavadas (2008) proposed a methodology to incorporate new parts, production mix changes and machines into an existing cellular manufacturing system. The objective is to fit the new parts and machines into an existing cellular manufacturing system thereby increasing machine utilizationand reducing investment in new equipment.

Viguier and Pierreval (2004) proposed an evolutionary programming algorithm to design a hybrid cellular manufacturing system. The hybrid cellular manufacturing system is composed by classical cells and functional cells (i.e. cells composed of machines of the same type). The proposed algorithm is illustrated on a test example with a known optimum.

Mak et al. (2007) presented a methodology to solve the manufacturing cell creation and the production scheduling problems for designing virtual cellular manufacturing systems. The methodology is based on ant colony optimization algorithm and two simple heuristics are developed to assign workstations to the operations of the jobs, and to construct the final schedule. Numerical experiments showed that the proposed algorithm generates excellent final solutions in a much shorter computation time when compared with the genetic algorithm.

Kesen et al. (2009) developeda multi-objective mixed integer programming formulation for job scheduling in virtual manufacturing cells. The objective function is to minimize the sum of the makespanand total traveling distance/cost.

Balakrishnan and Cheng (2007) presented a review research that has been done to address cellular manufacturing of multi period planning horizons, with demand and resources uncertainties. The authors identify, among future areas for research the following: "Comparison of dynamic cells (in which physical 
cells are reconfigured periodically) versus robust cells (in which cells stay static and uncertainties are managed through strategies such as VCMS) is needed to identify the conditions under which one would be favoured over the other"

Hoeck (2008) proposed an approach for order release and loading problem in a flexible manufacturing cell environment. The workload control approach involves three steps: lead orders are identified; transfer batches of the lead part types are calculated; workload of the machining centres is determined. A simulation environment was used to test the proposed approach.

Drolet et al. (2008) discussed the results of a simulation-based performance comparison between dynamic cellular manufacturing systems and two other well-known systems as classical cells and job shop systems. The experiments conducted regard 13 independent variables related to sources of turbulence and 17 independent variables related to performance measures. The research highlighted in what conditions one system is better than the others.

Renna and Padalino (2009) and Renna et al. (2008) proposed an innovative decision making strategy for autonomous agents in a cellular manufacturing environment by a budget assigned to each job in order to purchase manufacturing cell services. The budget manages as a market like approach among agents to coordination the multi agent system. Moreover, a fuzzy tool has been proposed to assign the budget to each typology job. A simulation environment is developed in order to test the proposed approach. The simulations show that the proposed approach is robust and a scheduling approach able to select the jobs that have been the better performance.

From the analysis of the literature, the following issues can be drawn:

- few papers investigated the performance comparison between cellular manufacturing systems with remainder cells and other configurations. In thesepapers, the remainder cell is used as a secondary cell that can be used when the manufacturing cells are affected by machine breakdowns.

- most of the researches consider one uncertainty between mix and volume products. Moreover, a research on the rapidity change of volume and mix products was not discussed in literature. The discussion in the literature concerns the amplitude of variability of the uncertain (as the standard deviation of stochastic demand).

The aim of this paper is to overcome the above limitations, developing loading approaches in hybrid cellular manufacturing systems composed by classical cells and remainder cells. The use of an opportune loading approach allows to response tomarket changes (volume and mix) avoiding the reconfiguration of the manufacturing cells.Then, a simulation environment has been developed in order to test the proposed approaches introducing market fluctuations (mix and inter-arrival demand) and evaluate the effect of rapidity change of the conditions. A wide range of performance measures are investigated using a classical CMS as a benchmark. The number of machines is the same for all configurations; therefore, the comparison is evaluated in a mid-term horizon in which only the different configuration is evaluated.

\section{Manufacturing system context}

The configurations of the manufacturing system investigated are: classical cellular manufacturing and hybrid cellular with a remainder cell. The objective of this research is the comparison of the performance in different conditions; therefore, the composition of the manufacturing cells is known. It has been considered three part families that are manufactured by three manufacturing cells. Then, the configuration with remainder cell is composed by the same number of machines ( $N$ machines) re-arranged to include in the manufacturing system the remainder cell. Therefore, the comparison is performed with the same machines changing only the configuration. The demand is not known at priori, and it follows an exponential distribution. Each cell is assumed to be independent, i.e. each family partperforms all the operations in only 
one cell.Set-up times are assumed to be zero, because the machines of the manufacturing cells are configured for the particular part family (dedicated machines). The machines of the remainder cell are general purpose machines; therefore, they have a processing timegreater than the machines in the manufacturing cells. This increment of processing time is due to the machines that are able to manufacture all part families. The processing time of machine $i$-th in remainder cell $r p t_{i r}$ is greater than the processing time of the machine $i$-th in the cell $j$-th $\left(p t_{i j}\right)$. The processing times are correlated by the following expression:

$$
\alpha=\frac{p t_{i r}}{p t_{i j}}, \alpha \geq 1
$$

The cellular manufacturing system has been designed for specific conditions; then, several disturbances have been introduced. These disturbances can be external (demand volatility) or internal (machine breakdowns). In this paper, it has been introduced the following disturbances:

- demand volatility; the volatility has been considered in term of mix fluctuation that changes the volume of each part family. Therefore, the workload of the manufacturing cells changes dynamically. Moreover, it has been considered volume fluctuations requested (inter-arrival time) by the market.

- machine breakdowns; each machine can breakdown randomly with a reduction of the productivity of the manufacturing cells.

Figure 1 shows the classical cellular manufacturing system, where each part family is assigned to the related manufacturing cell designed.

[Insert figure 1 here]

Figure 2 shows the hybrid configuration with the remainder cell. In this case, each part of a family has two possible routings: the manufacturing cell assigned and the remainder cell (the arrows of the figure 2 show the possible routing). The "cell loading policy" controller implements the strategy in order to decide the routing between the two possibilities when a part enters in the manufacturing system. The machines assigned to the reminder cellare able to perform any manufacturing operations required by all part families. The proposed strategies are deeply described in the following paragraph.

[Insert figure 2 here]

\section{Loading approaches}

The loading approach regards the hybrid manufacturing system with remainder cell; the problem is to decide when a part of a generic family can be manufactured by the remainder cell instead of the manufacturing cell. In literature, the remainder cell is used when an exception occurssuch as machine breakdowns. In this paper, three methodologies are proposed to use the remainder cell to keep a high performance level of the entire manufacturing system. The loading approaches proposed are based on the evaluation of the Work InProcess (WIP) of the manufacturing cells: local approach, global and global exclusive approaches.

\subsection{Local approach}


The loading policy is based on evaluation of the state of each manufacturing cell compared to the state of the remainder cell. The controller of the generic cellj-th $\left(W I P_{j}\right)$ computes the work in process as the sum of the parts waiting in queuesof the machinesthat compose the cell.

$W I P_{j}=\sum_{i \in j} N Q i$

where $N Q_{i}$ is the number of parts waiting in the machine's queuei-th computed for the machines of the cell j-th.

When a part arrives in the manufacturing system, the controller will decide if the part enters to the manufacturing cell designedfor its family or the part entersto the remainder cell (rsubscript). The decision is based on the following conditions computed for all manufacturing cells.

$W I P_{j} \geq W I \mathrm{P}_{\mathrm{r}}$

$W I P_{j}<W I \mathrm{P}_{\mathrm{r}}$

The manufacturing cells that verified the condition (3) re-route the parts to the reminder cell. While, the manufacturing cells that verify the condition (4) don't re-route the parts. Therefore, the generic part of a family is loaded in $j$-th manufacturing cell(designed for the part family), if the condition (4) is verified, otherwise it is loaded in remainder cell.

This approach allows to limit the level ofthe work in process in the manufacturing cells and, therefore, reducing throughput time and delay of the parts. The main drawback is the possibility toincrease the work in process in the remainder cell reducing the performance of the parts worked in this cell. This increment is due to the decision strategy; the expressions 3 and 4 don't take into account the global state of the manufacturing system. Each manufacturing cell decides the re-routing of the parts independently. The advantage of this approach is the reduction of communication; each manufacturing cell to take the decision needs to know only the state of the remainder cell.

\subsection{Global approach}

This approach is proposed to avoid the drawback of the local approach evaluating the global state of the manufacturing system. In this case, each manufacturing cell computes a congestion level $\left(\right.$ cong $\left._{j}\right)$ related to the WIP of the manufacturing system by the following expression:

cong $_{j}=\frac{W I P_{j}}{\sum_{i=1}^{M} N Q i} \in[0,1]$

whereWIP ${ }_{j}$ is the same value computed in expression (2) and the denominator is the sum of the parts in the queue for all machines $(M)$ of the manufacturing system (the work in process of the entire manufacturing system is the global information).

The part assigned to the generic $j$-th manufacturing cell has to be re-routed to the remainder cell, if two conditions are verified. The first is the following:

cong $_{j}=$ MAX $\left[\right.$ cong $_{1}$, cong $_{2}, \ldots . . .$, cong $\left._{N}\right]$

The expression (6) means that the manufacturing cellj-th is the cell with maximum value of the work in process compared to other manufacturing cells ( $N$ is the number of manufacturing cells). 
The second condition is the following:

$W I P_{j}-W I \mathrm{P}_{\mathrm{r}}>1$

Expression (7) means that the work in process of the manufacturing cell (j)has to be greater than the remainder cell $(r)$.The difference between the two cells has to be two parts. It is chosen this strategy in order to obtain a work in process of the remainder cell always lower than other manufacturing cells. In fact, if the second part of the expression (7) is zero, when the part enters the remainder cell the two cells have the same work in process. Applying this methodology, the remainder cell plays a role in supporting the main manufacturing cells.

Following this policy, only, the manufacturing cell with higher WIP re-route the parts. However, if the WIP of some manufacturing cells are equal, many parts can be re-route to the remainder cell. For this reason, a modification of this approach is proposed in the following sub-section.

\subsection{Global approach exclusive}

This approach is simply an adjustment of the previous approach. In some cases, the conditions (6) and (7) can be verified for more than one manufacturing cell. In this approach only one manufacturing cell can reroute the part, if more cells can re-route the part at the same time. In particular, the first manufacturing cell thatverifies the expressions (6) and (7) can re-route the part.This approach leads to reduce the utilization of the remainder cell.

\section{Simulation environment}

The objective of the simulation experiments is to measure the performance of proposed approaches benchmarked to a classical cellular manufacturing system in a very dynamic environment. The authors selected the Arena ${ }^{\circledR}$ discrete event simulation platform by Rockwell Software Inc. it was used to develop the simulation model of the presented approaches.Discrete event simulation - in many commercial tools and simulation packages, nowadays the simulation model is automatically created from high level modeling languages and notations - allows to validate and optimize dynamic and discrete systems such as production systems, but also workflows such as negotiation mechanisms. These models facilitate evaluating different coordination scenarios and maximizing their potential output and benefits. Arena ${ }^{\circledR}$ - based on the known SIMAN simulation language - is well suited for modeling shop floors of production systems in which each entity (part) follows a manufacturing route through production resources (servers, material handling systems, buffers, and so forth), (Kelton and Sadowski, 2009).The manufacturing system consists of ten machines $(M=10)$, and it has been considered three part families. The configurations of the manufacturing system have to implement three manufacturing cells $(N=3)$. Table 1 reports the mix for each part family.

\section{[Insert table1 here]}

In the caseof the cellular manufacturing system (used as a benchmark), it has been designed two manufacturing cells with four machines for the part 1 and 2 (the two families have the same part mix); the third manufacturing cell is composed by twomachines for the part 3 (lower value of mix). The configuration with the remainder cell consists of three manufacturing cells, but some machines need to be used in the remainder cell and subtracted from the manufacturing cells of the cellular manufacturing system. In this case,the configuration is the following: three machines are assigned for each manufacturing cell dedicated to part 1 and 2; two machines are assigned for the manufacturing cell dedicated to the part 3; two machines are assignedto the remainder cell. The machines assigned to the reminder cell perform the manufacturing operations with higher processing time (see equation 1), because these machinesare general 
purpose in order to perform any kind of operations. Figure 3 shows the cellular manufacturing system used for the simulation experiments with the assignment of the machines to the cells.

[Insert figure 3 here]

Figure 4 shows the re-configuration of the machines 4 and 8 to form the remainder cell. These machines are configured to perform any kind of operations required by the three part families.

\section{[Insert figure 4 here]}

Table 2 reports the processing time of the machines in the two configurations investigated.

\section{[Insert table2 here]}

The total time to manufacture the parts is 40 equal for all part families; in this way, the performance comparison is due only to the different configurations. The total processing time is distributed to the machines uniformly. In the case of cellular manufacturing configuration, the machines from 1 to 4 (cell 1 ) have a processing time of 10 unit times in order to perform all the processing time required (40 unit times); the same processing times are assigned to the machines from 5 to 8 (cell 2); while the machines 9 and 10 (cell 3) have 20 unit times. In case of remainder cell introduction, the cells 1 and 2 have three machines with a processing time of 13.33 unit times. The machines 4 and 8 assigned to the remainder cell have a processing time of 24 unit times. It is assigned a value of $\alpha=1.2$ (see equation 1); the processing time of general purpose machines of remainder cell isgrater of $20 \%$ than the machines of a cell that are specifically configured for a part family. This choice overestimates the difference of processing time between dedicated and general purpose machines. However, the focus of this paper is the evaluation of the behavior of loading approaches; the study of $\alpha$ will be associated with the economic evaluation of the investment in machines. Parts enter the system following an exponential arrival stream whose inter-arrival times are reported intable 3. The simulations are performed for four congestion levels of the manufacturing system.

\section{[Insert table3 here]}

Several experiments have been conducted in order to set the inter-arrival time; the values reported in table 3 allow to obtain an order of magnitude of average utilization of the manufacturing system. These interarrival times allow to investigate several degrees of congestion of the manufacturing system.

A due date is assigned to the parts by the following expression:

due date $=40 \bullet$ duedate $_{\text {index }}$

The due date is obtained by the technological processing time (40 unit times) multiplied with an index; this index is 1.5 for parts 1 and 2, while it is one for part 3 (part 3 has a low part mix). However, the objective of the research is the comparison of the performance; therefore, the choice of thedue date index does not affect the analysis.

Concerning the machine breakdowns, it has been assumed that all the manufacturing machines are subject to faults; Mean Time Between Failures (MTBF) is distributed according to thenormally distribution, with mean 2000 unit times and variance 200 unit times. Mean Time To Repair (MTTR) follows a normal distribution with mean 40unit times and variance 6 unit times (equal for all machines). 


\section{Simulation results}

The proposed approaches are tested in static and dynamic situations; the dynamicity of the manufacturing system is characterized by the stage length andthe simulation length is fixed to 43200 time units. In order to emulate a market dynamic environment the demand characteristics (inter-arrival time and product mix) changing during the production run consisting of several alternating stages. Four stage lengths have been considered; table 4 reports the stage length and the number of changes (demand characteristics) that occur over the entire simulation horizon.

\section{[Insert table4 here]}

Table 5 describes the design of the simulation experiments conducted for the two configurations of the manufacturing system. Combining the four inter-arrival times, four stage length and the two demand changes (mix and inter-arrival) and the static condition (without any changes) it has been obtained 28 experimental classes.

\section{[Insert table5 here]}

The two demand changes are obtained by the following expressions:

$$
\text { mix product }{ }_{p}{ }_{p}=\operatorname{mix} \text { product }_{p} \bullet \text { UNIFORM[0.9,1.1], for product } p=1,2,3 \text {; }
$$

Expression (9) means that the mix of the products (for which the cellular manufacturing systems were designed, mix product $\left.{ }_{p}\right)$ is affected by a variation of $20 \%$ (1.1-0.9) extracted by a uniform distribution.

int er - arrival $^{*}=5.5 \bullet$ UNIFORM[0.9,1.1]

Expression (10) computes the inter-arrival time of the parts starting from 5.5 multiplied for an uncertain of $20 \%$ extracted by a uniform distribution. The value 5.5 of inter-arrival time assures a medium level of average utilization of the manufacturing system about 70\%.The inter-arrival and mix changes are computed for each alternation between two consequently stages. The uniform distribution is used to simulate demand and mix random fluctuations. For each experiment class, a number of replications able to assure a $5 \%$ confidence interval and $95 \%$ of confidence level for each performance measure have been conducted. The performance measures investigated are the following:

- $\quad$ Throughput time for each part $j$ (thr. Time $j$ );

- Average throughput time (average thr. Time);

- Throughput (thr.);

- Work In Process (WIP);

- Average utilization of the manufacturing system (av. utilization);

- Total tardiness time of the parts (tardiness).

The results reported in the following tables and figures are an elaboration of the simulation results reported in the appendix. Table 6 reports the percentage difference among the proposed approaches and cellular manufacturing system (used as the base for percentage computation), when the environmental conditions are static and without machine breakdowns. Table 6 reports the average value and the standard deviation of the performance over the congestion levels. The average values show the difference among the approaches if the congestion levels have the same probability to occur. The standard deviation (dev.st)is an index of the performance variation whenthe congestion level changes (robustness).

\section{[Insert table6 here]}

The results of the table 6 show that in a static condition and without machine breakdowns, the cellular manufacturing system leads to the better performance level. Only, the throughput time of the part 3 
improves, because the remainder cell can support the related manufacturing cell when the peakof $\mathrm{WIP}_{3}$ occurs. The influence of congestion levels is very low except for tardiness and throughput time of the part 3 (see dev.st of table 6).Table 7 reports the same analysis of table 6 withmachine breakdowns.

\section{[Insert table7 here]}

From the analysis of table 7 the following issues can be drawn:

- The local approach leads to performance very close to the cellular manufacturing system, except for the tardiness performance. In fact, the main benefit of this approach is the reduction of the tardiness (average of 16\%).

- The global approach leads to worst performance for all measures, except the throughput time of the part 3 . However, the average throughput time getsworse than the cellular manufacturing system. The global approach exclusive reduces the deterioration of the performance, but the performance measures are worse than the cellular manufacturing system.

- Generally, the performance measures that are influenced by the congestion level are the tardiness and the throughput time of the part 3 (for these performance measuresthe standard deviation is relevant).

Table 8 reports the percentage difference among the proposed approaches and the cellular manufacturing system for different congestion levels, when mix fluctuations are present. The values reported are the average over the different stage lengths; the performance measures have a low dependence on stage length (as showed in appendix with the numerical results).

\section{[Insert table8 here]}

In these environmental conditions, the proposed approaches lead to better results for all performance measures of the manufacturing system: reduction of average throughput time, reduction of work in process and reduction of tardiness. The global approach and global approach exclusive increase the benefit compared tothe cellular manufacturing system. It can be noticed that the reduction of throughput time is obtained for all family parts, whilethe local approach reduces only the throughput time of the part 3. Moreover, the performance measures of the global and global exclusive have a greaterdependence on the congestion levels than the local (see dev.st). In particular, the benefits of two global approaches are relevant incases of medium and high congestion levels (inter-arrival 4.5 and 5), while in case of low congestion level (inter arrival 7) the performance measures areworse than the cellular manufacturing system.

Table 9 reports the simulation results when the inter-arrival fluctuation is present. Also, in this case the values are the average over the stage lengths.

\section{[Insert table9 here]}

The results show how the proposed approaches lead to better results when the inter-arrival fluctuation occurs. The improvement of the performance is better for the global and global exclusive approaches (very similar between them).The stage length has a low influence on the results' comparison, because the standard deviation values are very low. The above comments are valid when the inter-arrival and mix fluctuations are present together (see table 10). In this case, the improvements are greater than the case of only inter-arrival fluctuations.

\section{[Insert table10 here]}

In summary, the three performance measures with higher improvement are: average throughput time, work in process and tardiness. Figures $5 \mathrm{a}, 5 \mathrm{~b}$ and $5 \mathrm{cshow}$ the percentage difference among the proposed 
approaches and the cellular manufacturing system over the different unforeseen events considered. As the reader can notice, when the conditions are static the approach with remainder cell leads to worst performance while, the loading approaches with remainder cell lead to better performance measures with the introduction of exceptions (mix and inter-arrival fluctuations and machine breakdowns).

[Insert figure 5 here]

\section{Conclusions and future development}

The paper proposesloading policies for cellular manufacturing systems with a general purpose cell defined in literature reminder cell. A simulation environment has been developed to test the proposed approaches compared to a classical cellular manufacturing system. The simulations have been conducted in static conditions and in a very dynamic environment with market changes (mix and inter-arrival time fluctuations) and machine breakdowns. The results of this research can be summarized as it follows:

- The cellular manufacturing configuration is better when the market conditions are static, this validates the benchmark developed;

-The proposed loading policies allow to obtain relevant improvements of the performance when mix fluctuations occur. The benefits are reduced when the inter-arrival fluctuations occur, but however, the proposed approaches are better than the cellular manufacturing configuration. The performance measurewith better improvement is the due date (tardiness). The performance of work in process and average throughput time are also improved.

- The two approaches with the better performance (global and global exclusive)have higherdependence on the congestion levels, whilethelocal approach is more robust.

- The better performance of the global approaches than the local approach underlines that the decision taken on global information can lead to relevant improvements of the performance measures.

- Finally, the low values of standard deviation when external and internal exceptions occur (see table 10) show that the proposed approaches are robust to the rapidity change of the manufacturing system conditions.

In briefly, the remainder cell was used in literature as a cell to support the manufacturing cells when machine breakdowns occur; the loading policies proposed show how the remainder cell can be used to keep a high level of performance when market fluctuations happen. The benefits of the remainder cell are evaluated when the processing time of the remainder cell is greater than the dedicated cell. This assumption is made to introduce the effect of the efficiency; general purpose machines can be less efficient than task-specific dedicated machines.

This strategy can avoid the re-configuration of cellular manufacturing systems when market conditions change, reducing costs and set-up times.

Future research paths concern the following issues. The performance measures of the hybrid cellular manufacturing system for different amplitude of market fluctuations. Another future research path is the evaluation of the increment of processing time for the machines assigned to the remainder cell. This analysis needs to be conducted with the related investment cost in machines, because the parameter $\alpha$ is strength related to the cost of machines. 


\section{References}

Askin R.G., Estrada S., (1999). Investigation of cellular manufacturing practices. In Irani S.A., editor. Handbook of cellular manufacturing systems. New York, John Wiley, 25-34.

Balakrishnan J. and Cheng C. H., (2007). Multi-period planning and uncertainty issues in cellular manufacturing: A review and future directions. European Journal of Operational Research, 177, 281-309.

Bhandwale A. andKesavadas T., (2008).A methodology to incorporate product mix variations in cellular manufacturing.Journal of IntelligentManufacturing, 19, 71-85.

Chen M., (1998).Amathematical programming model for system reconfiguration in a dynamic cellular manufacturing environment.Annals of operation research 1998, 74, 179-284.

Drolet J., Marcoux Y. and Abdulnour G., (2008). Simulation-based performance comparison between dynamic cells, classical cells and job shops: a case study. International Journal of Production Research, 46(2), 509-536.

Huang M. G., Chang P. L. and Chou Y. C., (2003). Fast Algorithm for Evaluating the Similarity of Manufacturing Processes within Dynamic Production Environment. International Journal of Production Research, 41 (17), 4171-4183.

Hoeck M., (2008). A workload control procedure for an FMC integrated in a job shop. International Journal of Computer Integrated Manufacturing, 21 (6), 666-675.

Kelton W. D. andSadowski R. P., (2009).Simulation with Arena.McGraw-Hill.

Kesen S. E., Das S. K. andGungor Z., (2009).A mixed integer programming formulation for scheduling of virtual manufacturing cells (VMCs). International Journal of AdvancedManufacturing Technology, DOI 10.1007/s00170-009-2231-4.

Maddisetty S., (2005) .Design of shared cells in a probabilistic demand environment. Ph.D. Thesis, College of Engineering and Technology of Ohio University.

Mak K. L. and Wong Y. S., (2000).Product Grouping and Resource Allocation in Multiline Manufacturing Systems. International Journal of Advanced Manufacturing Technology, 16, 917-926.

Mak K. L., Peng P., Wang X. X., T. L. Lau T. L., (2007). An ant colony optimization algorithm for scheduling virtual cellular manufacturing systems. International Journal of Computer Integrated Manufacturing, 20 (6), 524-537.

McLeanC.R.,BloomH. M.,HoppT. H., (1982).Thevirtualmanufacturingcell.In Proceedings of thefourthIFAC/IFIPconference on information control problems in manufacturing technology,Gaithersburg,M.D.,1-9. 
Montreuil B., LeFrancois P., Marcotte S., VenkatadriU., (1993).Holographic layout of manufacturing systems operating in chaotic environments.Technical report, 53-93, Document de Recherghe GRGL, Faculte des Sciences de l'Administration, University Laval, Quebec.

Montreuil B., VenkatadriU., Rardin R. L., (1999). Fractal layout organization for job shop environments.International Journal of Production Research, 37 (3), 501-521.

Renna P., Padalino, R., and Vancza, J., (2008). A Multi-Agent Architecture for Budget-based Scheduling in Dynamic Environments, 6th CIRP Int. Conf. on ICME, Naples, Italy, 23 - 25 July.

Renna P., Padalino R.,(2009). Adaptive Dynamic Scheduling in Agent Based Manufacturing Environment: A Budget Approach. Communications of the IBIMA, 7, 28-35.

Saad S. M., Gindy N.Z. and Baykasoghu A., (2002). A new integrated system for loading and scheduling in cellular manufacturing. International journal of computer integrated manufacturing, 15(1), 37-49.

Safaei N., Saidi-Mehrabad M. Babakhani M., (2007). Designing cellular manufacturing systems under dynamic and uncertain conditions.Journal of Intelligent Manufacturing, 18, 383-399.

Süer G. A., Huang J. and MaddisettyS., (2009).Design of dedicated, shared and remainder cells in a probabilistic demand environment.International Journal of Production Research,DOI: 10.1080/00207540903117865.

TompkinsJ. A.,WhiteJ. A.,BozerY. A. ,Tanchoco J. M.A., (2003). Facilities planning.New York,Wiley.

Venkatadri U., Rardin R. L., Montreuil B., (1997).A design methodology for fractal layout organization.IIE Transactions, 29, 911-924.

Viguier F., Pierreval H. (2004). An approach to the design of a hybrid organization of workshops into functional layout and group technology cells. International Journal of Computer Integrated Manufacturing, 17(2), $108-116$. 


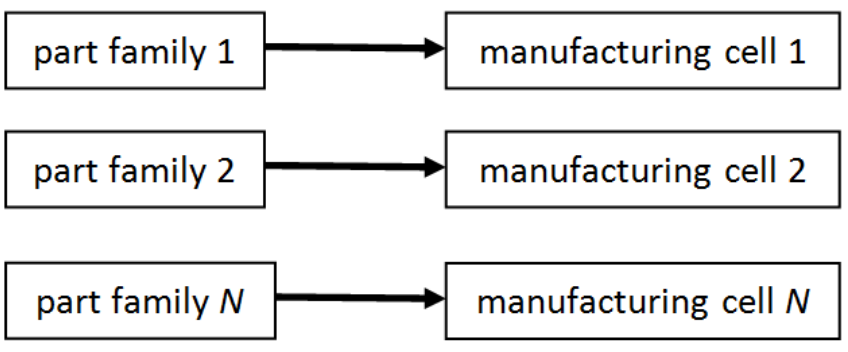

Figure 1. Cellular manufacturing system 


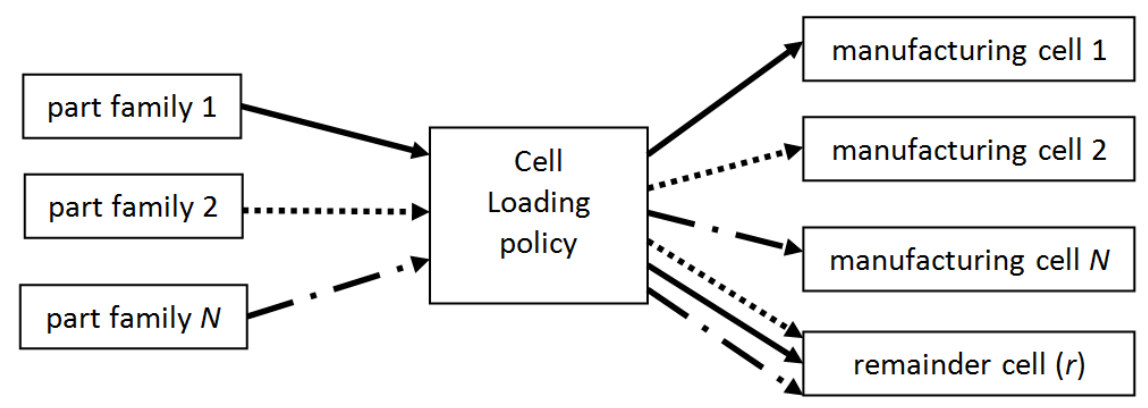

Figure 2. Cellular manufacturing system with remainder cell 


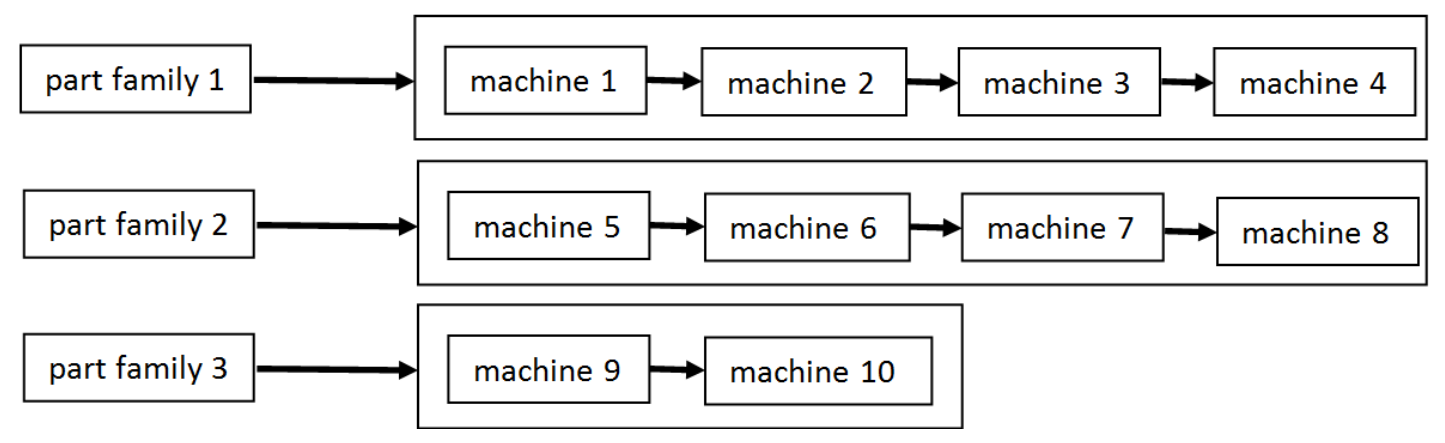

Figure 3. Cellular manufacturing system 


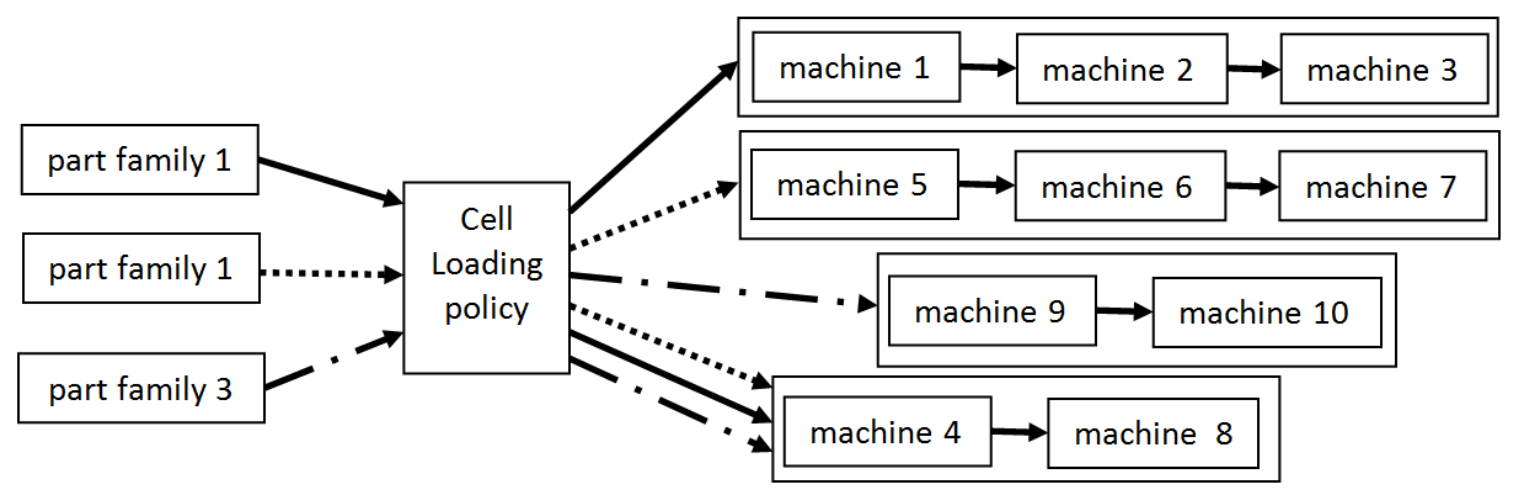

Figure 4. Cellular manufacturing system with remainder cell 


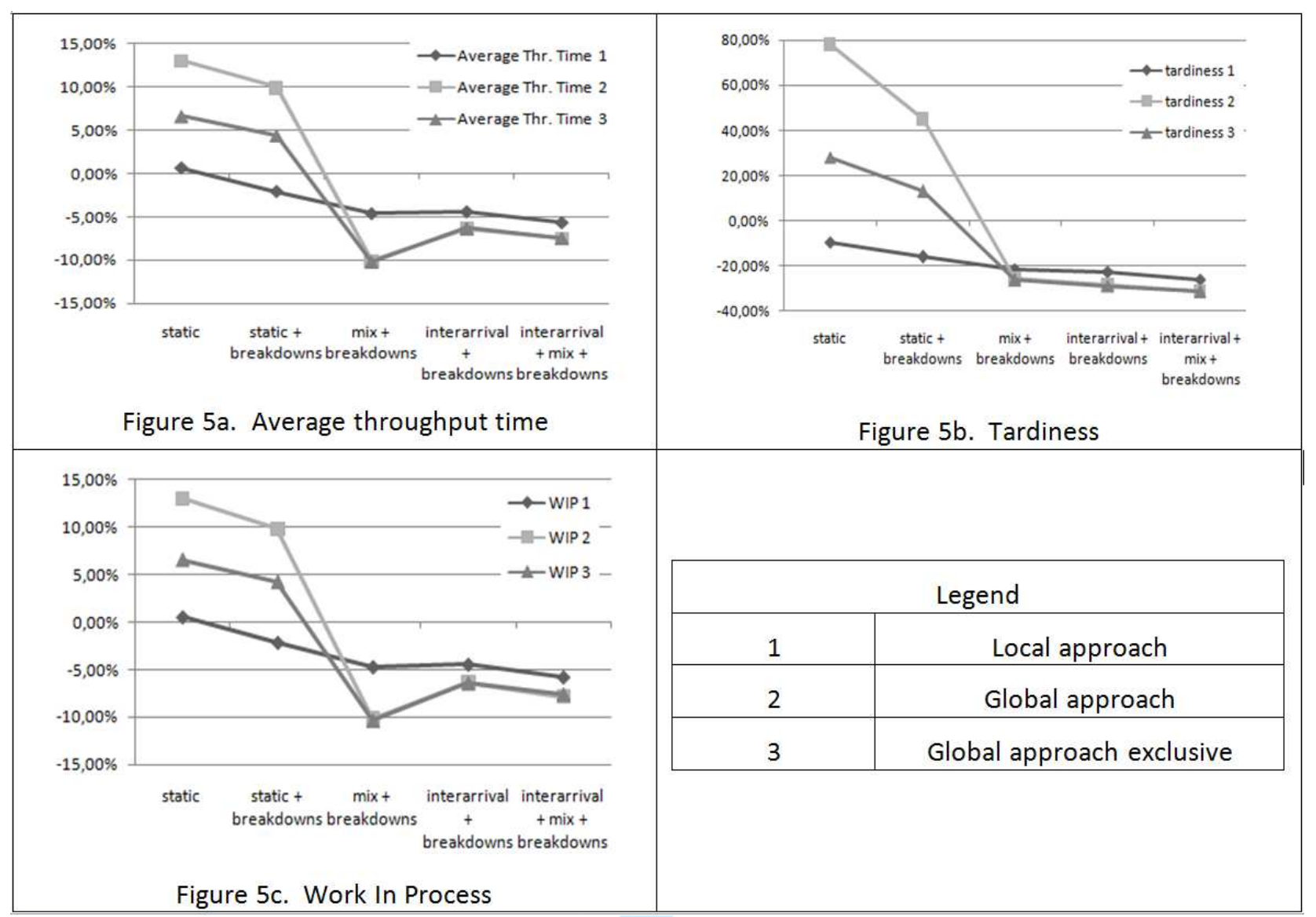




\begin{tabular}{cccc}
\hline & Part 1 & Part 2 & Part 3 \\
\hline Part mix & $40 \%$ & $40 \%$ & $20 \%$ \\
\hline
\end{tabular}

Table 1. Partmix 


\begin{tabular}{cccccc}
\hline & machine 1 & machine 2 & machine 3 & machine 4 & machine 5 \\
\hline Processing time (cellular) & 10 & 10 & 10 & 10 & 10 \\
\hline Processing time (remainder) & 13.33 & 13.33 & 13.33 & 24 & 13.33 \\
\hline & machine 6 & machine 7 & machine8 & machine 9 & machine 10 \\
\hline Processing time (cellular) & 10 & 10 & 10 & 20 & 20 \\
\hline Processing time (remainder) & 13.33 & 13.33 & 24 & 20 & 20 \\
\hline
\end{tabular}

Table 2. Processing times 


\begin{tabular}{ccccc}
\hline & int 1 & int 2 & int 3 & Int 4 \\
\hline Inter arrival time parameter [unit times] & 4.5 & 5 & 6 & 7 \\
\hline Average utilization [order of magnitude] & 0.9 & 0.8 & 0.65 & 0.55 \\
\hline
\end{tabular}

Table 3. Inter-arrival time 


\begin{tabular}{cc}
\hline Stage length & Number of changes \\
\hline $\mathbf{8 6 4 0}$ & 5 \\
$\mathbf{4 3 2 0}$ & 10 \\
$\mathbf{2 8 8 0}$ & 15 \\
\hline $\mathbf{2 1 6 0}$ & 20 \\
\hline
\end{tabular}

Table 4. Stage length 


\begin{tabular}{|c|c|c|c|c|}
\hline Exp. no. & Inter-arrival & Stage length & Mix changes & Inter-arrival changes \\
\hline 1 & 4.5 & Static & no & no \\
\hline 2 & 5 & Static & no & no \\
\hline 3 & 6 & Static & no & no \\
\hline 4 & 7 & Static & no & no \\
\hline 5 & 4.5 & 8640 & yes & no \\
\hline 6 & 5 & 8640 & yes & no \\
\hline 7 & 6 & 8640 & yes & no \\
\hline 8 & 7 & 8640 & yes & no \\
\hline 9 & 4.5 & 4320 & yes & no \\
\hline $\mathbf{1 0}$ & 5 & 4320 & yes & no \\
\hline 11 & 6 & 4320 & yes & no \\
\hline 12 & 7 & 4320 & yes & no \\
\hline 13 & 4.5 & 2880 & yes & no \\
\hline 14 & 5 & 2880 & yes & no \\
\hline 15 & 6 & 2880 & yes & no \\
\hline 16 & 7 & 2880 & yes & no \\
\hline 17 & 4.5 & 2160 & yes & no \\
\hline 18 & 5 & 2160 & yes & no \\
\hline 19 & 6 & 2160 & yes & no \\
\hline 20 & 7 & 2160 & yes & no \\
\hline 21 & 5.5 & 8640 & no & yes \\
\hline 22 & 5.5 & 4320 & no & yes \\
\hline 23 & 5.5 & 2880 & no & yes \\
\hline 24 & 5.5 & 2160 & no & yes \\
\hline 25 & 5.5 & 8640 & yes & yes \\
\hline 26 & 5.5 & 4320 & yes & yes \\
\hline 27 & 5.5 & 2880 & yes & yes \\
\hline 28 & 5.5 & 2160 & yes & yes \\
\hline
\end{tabular}

Table 5. Experimental plan 


\begin{tabular}{|c|c|c|c|c|c|c|c|c|}
\hline & $\begin{array}{c}\text { Thr. } \\
\text { Time } 1\end{array}$ & $\begin{array}{c}\text { Thr. } \\
\text { Time } 2\end{array}$ & $\begin{array}{c}\text { Thr. } \\
\text { Time } 3\end{array}$ & $\begin{array}{l}\text { Average } \\
\text { Thr. time }\end{array}$ & Thr. & WIP & $\begin{array}{c}\text { Av. } \\
\text { utilization }\end{array}$ & tardiness \\
\hline \multicolumn{9}{|c|}{ Local approach } \\
\hline Average & $8.69 \%$ & $8.71 \%$ & $-22.87 \%$ & $0.66 \%$ & $-0.13 \%$ & $0.57 \%$ & $3.27 \%$ & $-9.48 \%$ \\
\hline Dev.st & $5.02 \%$ & $4.88 \%$ & $12.65 \%$ & $1.79 \%$ & $0.28 \%$ & $1.71 \%$ & $1.78 \%$ & $6.89 \%$ \\
\hline \multicolumn{9}{|c|}{ Global approach } \\
\hline Average & $23.83 \%$ & $23.73 \%$ & $-19.07 \%$ & $13.04 \%$ & $-0.05 \%$ & $13.02 \%$ & $3.47 \%$ & $77.87 \%$ \\
\hline Dev.st & $2.78 \%$ & $2.84 \%$ & $12.54 \%$ & $3.13 \%$ & $0.23 \%$ & $3.18 \%$ & $1.95 \%$ & $65.74 \%$ \\
\hline \multicolumn{9}{|c|}{ Global approach exclusive } \\
\hline Average & $15.80 \%$ & $15.78 \%$ & $-20.55 \%$ & $6.62 \%$ & $-0.08 \%$ & $6.57 \%$ & $3.01 \%$ & $27.94 \%$ \\
\hline Dev.st & $4.28 \%$ & $4.50 \%$ & $12.30 \%$ & $2.17 \%$ & $0.18 \%$ & $2.21 \%$ & $1.60 \%$ & $27.36 \%$ \\
\hline
\end{tabular}

Table 6. Simulation results - static environment without machine breakdowns 


\begin{tabular}{ccccccccc}
\hline $\begin{array}{c}\text { Inter- } \\
\text { arrival }\end{array}$ & $\begin{array}{c}\text { Thr. } \\
\text { Time 1 }\end{array}$ & $\begin{array}{c}\text { Thr. } \\
\text { Time 2 }\end{array}$ & $\begin{array}{c}\text { Thr. } \\
\text { Time 3 }\end{array}$ & $\begin{array}{c}\text { Average } \\
\text { Thr. time }\end{array}$ & Thr. & WIP & $\begin{array}{c}\text { Av. } \\
\text { Local appraoch }\end{array}$ & tardiness \\
\hline \multicolumn{7}{c}{ utilization } & \\
\hline Average & $5.08 \%$ & $4.60 \%$ & $-24.04 \%$ & $-2.04 \%$ & $-0.08 \%$ & $-2.12 \%$ & $4.25 \%$ & $-16.00 \%$ \\
\hline Dev.st & $6.43 \%$ & $5.53 \%$ & $12.16 \%$ & $3.16 \%$ & $0.05 \%$ & $3.19 \%$ & $0.44 \%$ & $10.27 \%$ \\
\hline \multicolumn{7}{c}{ Global approach } \\
\hline Average & $17.79 \%$ & $18.96 \%$ & $-20.17 \%$ & $9.96 \%$ & $-0.16 \%$ & $9.86 \%$ & $4.26 \%$ & $44.88 \%$ \\
\hline Dev.st & $2.69 \%$ & $3.47 \%$ & $12.32 \%$ & $3.67 \%$ & $0.10 \%$ & $3.63 \%$ & $0.38 \%$ & $41.22 \%$ \\
\hline \multicolumn{7}{c}{ Global approach exclusive } \\
\hline Average & $12.69 \%$ & $12.11 \%$ & $-21.45 \%$ & $4.40 \%$ & $-0.14 \%$ & $4.27 \%$ & $0.85 \%$ & $12.97 \%$ \\
\hline Dev.st & $5.69 \%$ & $4.66 \%$ & $11.84 \%$ & $2.94 \%$ & $0.23 \%$ & $2.78 \%$ & $4.84 \%$ & $15.00 \%$ \\
\hline
\end{tabular}

Table 7. Simulation results - static environment with machine breakdowns 


\begin{tabular}{|c|c|c|c|c|c|c|c|c|}
\hline $\begin{array}{c}\text { Inter- } \\
\text { arrival }\end{array}$ & $\begin{array}{c}\text { Thr. } \\
\text { Time } 1\end{array}$ & $\begin{array}{c}\text { Thr. } \\
\text { Time } 2\end{array}$ & $\begin{array}{c}\text { Thr. } \\
\text { Time } 3\end{array}$ & $\begin{array}{c}\text { Average } \\
\text { Thr. time }\end{array}$ & Thr. & WIP & $\begin{array}{c}\text { Av. } \\
\text { utilization }\end{array}$ & tardiness \\
\hline \multicolumn{9}{|c|}{ Local approach } \\
\hline 4.5 & $5.88 \%$ & $5.52 \%$ & $-43.67 \%$ & $-6.83 \%$ & $-0.02 \%$ & $-6.87 \%$ & $3.66 \%$ & $-13.08 \%$ \\
\hline 5 & $-0.25 \%$ & $-0.78 \%$ & $-31.34 \%$ & $-7.91 \%$ & $0.04 \%$ & $-7.88 \%$ & $4.14 \%$ & $-25.73 \%$ \\
\hline 6 & $1.18 \%$ & $1.46 \%$ & $-18.11 \%$ & $-3.09 \%$ & $-0.10 \%$ & $-3.16 \%$ & $4.43 \%$ & $-25.26 \%$ \\
\hline 7 & $2.80 \%$ & $2.87 \%$ & $-12.21 \%$ & $-0.48 \%$ & $-0.32 \%$ & $-0.82 \%$ & $4.14 \%$ & $-21.83 \%$ \\
\hline Average & $2.40 \%$ & $2.27 \%$ & $-26.33 \%$ & $-4.58 \%$ & $-0.10 \%$ & $-4.68 \%$ & $4.09 \%$ & $-21.48 \%$ \\
\hline Dev.st & $2.63 \%$ & $2.64 \%$ & $14.06 \%$ & $3.42 \%$ & $0.16 \%$ & $3.28 \%$ & $0.32 \%$ & $5.86 \%$ \\
\hline \multicolumn{9}{|c|}{ Global approach } \\
\hline 4.5 & $-18.20 \%$ & $-18.61 \%$ & $-51.97 \%$ & $-26.96 \%$ & $0.00 \%$ & $-27.05 \%$ & $4.09 \%$ & $-46.21 \%$ \\
\hline 5 & $-6.82 \%$ & $-7.30 \%$ & $-34.29 \%$ & $-13.60 \%$ & $-0.04 \%$ & $-13.67 \%$ & $3.76 \%$ & $-39.39 \%$ \\
\hline 6 & $2.98 \%$ & $2.86 \%$ & $-18.57 \%$ & $-1.94 \%$ & $-0.05 \%$ & $-2.00 \%$ & $3.63 \%$ & $-18.02 \%$ \\
\hline 7 & $6.34 \%$ & $6.42 \%$ & $-12.13 \%$ & $2.32 \%$ & $-0.06 \%$ & $2.23 \%$ & $2.91 \%$ & $1.35 \%$ \\
\hline Average & $-3.93 \%$ & $-4.16 \%$ & $-29.24 \%$ & $-10.05 \%$ & $-0.04 \%$ & $-10.12 \%$ & $3.60 \%$ & $-25.57 \%$ \\
\hline Dev.st & $11.03 \%$ & $11.25 \%$ & $\mathbf{1 7 . 7 8 \%}$ & $13.13 \%$ & $\mathbf{0 . 0 3 \%}$ & $13.14 \%$ & $\mathbf{0 . 5 0 \%}$ & $21.59 \%$ \\
\hline \multicolumn{9}{|c|}{ Global approach exclusive } \\
\hline 4.5 & $-18.51 \%$ & $-18.84 \%$ & $-51.81 \%$ & $-27.12 \%$ & $0.06 \%$ & $-27.17 \%$ & $4.09 \%$ & $-46.50 \%$ \\
\hline 5 & $-7.36 \%$ & $-8.38 \%$ & $-34.32 \%$ & $-14.23 \%$ & $-0.08 \%$ & $-14.33 \%$ & $3.79 \%$ & $-41.23 \%$ \\
\hline 6 & $2.83 \%$ & $2.78 \%$ & $-18.55 \%$ & $-2.03 \%$ & $-0.02 \%$ & $-2.08 \%$ & $3.63 \%$ & $-18.77 \%$ \\
\hline 7 & $6.47 \%$ & $6.31 \%$ & $-12.02 \%$ & $2.35 \%$ & $-0.03 \%$ & $2.26 \%$ & $3.21 \%$ & $1.29 \%$ \\
\hline Average & $-4.14 \%$ & $-4.53 \%$ & $-29.18 \%$ & $-10.26 \%$ & $-0.02 \%$ & $-10.33 \%$ & $3.68 \%$ & $-26.30 \%$ \\
\hline Dev.st & $11.23 \%$ & $11.41 \%$ & $17.76 \%$ & $13.25 \%$ & $0.06 \%$ & $13.24 \%$ & $0.37 \%$ & $21.98 \%$ \\
\hline
\end{tabular}

Table 8. Simulation results - mix changes 


\begin{tabular}{|c|c|c|c|c|c|c|c|c|}
\hline Exp. no. & $\begin{array}{c}\text { Thr. } \\
\text { Time } 1\end{array}$ & $\begin{array}{c}\text { Thr. } \\
\text { Time } 2\end{array}$ & $\begin{array}{c}\text { Thr. } \\
\text { Time } 3\end{array}$ & $\begin{array}{l}\text { Average } \\
\text { Thr. time }\end{array}$ & Thr. & WIP & $\begin{array}{c}\text { Av. } \\
\text { utilization }\end{array}$ & tardiness \\
\hline \multicolumn{9}{|c|}{ Local approach } \\
\hline Average & $1.31 \%$ & $1.10 \%$ & $-23.05 \%$ & $-4.36 \%$ & $-0.02 \%$ & $-4.42 \%$ & $4.61 \%$ & $-22.70 \%$ \\
\hline Dev.st & $0.16 \%$ & $0.17 \%$ & $0.39 \%$ & $0.22 \%$ & $0.14 \%$ & $0.37 \%$ & $0.22 \%$ & $0.90 \%$ \\
\hline \multicolumn{9}{|c|}{ Global approach } \\
\hline Average & $-0.79 \%$ & $-1.01 \%$ & $-24.59 \%$ & $-6.34 \%$ & $0.07 \%$ & $-6.36 \%$ & $4.09 \%$ & $-28.56 \%$ \\
\hline Dev.st & $0.34 \%$ & $0.40 \%$ & $0.23 \%$ & $0.25 \%$ & $0.50 \%$ & $0.69 \%$ & $0.14 \%$ & $1.18 \%$ \\
\hline \multicolumn{9}{|c|}{ Global approach exclusive } \\
\hline Average & $-0.95 \%$ & $-1.05 \%$ & $-24.37 \%$ & $-6.36 \%$ & $0.00 \%$ & $-6.42 \%$ & $3.85 \%$ & $-28.85 \%$ \\
\hline Dev.st & $0.08 \%$ & $0.17 \%$ & $0.39 \%$ & $0.15 \%$ & $0.22 \%$ & $0.36 \%$ & $0.29 \%$ & $0.74 \%$ \\
\hline
\end{tabular}

Table 9. Simulation results - inter-arrival changes 


\begin{tabular}{|c|c|c|c|c|c|c|c|c|}
\hline Exp. no. & $\begin{array}{c}\text { Thr. } \\
\text { Time } 1\end{array}$ & $\begin{array}{c}\text { Thr. } \\
\text { Time } 2\end{array}$ & $\begin{array}{c}\text { Thr. } \\
\text { Time } 3\end{array}$ & $\begin{array}{l}\text { Average } \\
\text { Thr. time }\end{array}$ & Thr. & WIP & $\begin{array}{c}\text { Av. } \\
\text { utilization }\end{array}$ & tardiness \\
\hline \multicolumn{9}{|c|}{ Local approach } \\
\hline Average & $0.18 \%$ & $-0.11 \%$ & $-24.33 \%$ & $-5.61 \%$ & $-0.14 \%$ & $-5.76 \%$ & $3.73 \%$ & $-26.18 \%$ \\
\hline Dev.st & $0.25 \%$ & $0.12 \%$ & $0.52 \%$ & $0.22 \%$ & $0.26 \%$ & $0.39 \%$ & $1.03 \%$ & $0.77 \%$ \\
\hline \multicolumn{9}{|c|}{ Global approach } \\
\hline Average & $-1.63 \%$ & $-2.17 \%$ & $-26.04 \%$ & $-7.50 \%$ & $-0.32 \%$ & $-7.81 \%$ & $3.63 \%$ & $-31.50 \%$ \\
\hline Dev.st & $0.85 \%$ & $0.66 \%$ & $0.38 \%$ & $0.58 \%$ & $0.26 \%$ & $0.74 \%$ & $0.29 \%$ & $1.73 \%$ \\
\hline \multicolumn{9}{|c|}{ Global approach exclusive } \\
\hline Average & $-1.71 \%$ & $-2.20 \%$ & $-25.78 \%$ & $-7.49 \%$ & $-0.09 \%$ & $-7.56 \%$ & $3.63 \%$ & $-31.52 \%$ \\
\hline Dev.st & $0.57 \%$ & $0.43 \%$ & $0.25 \%$ & $0.38 \%$ & $0.17 \%$ & $0.40 \%$ & $0.35 \%$ & $1.18 \%$ \\
\hline
\end{tabular}

Table 10. Simulation results - inter-arrival and mix changes 


\section{APPENDIX}

WIP [parts]

Thr. Time [unit time]

Average Thr. Time [unit time]

Tardiness [unit time]

\begin{tabular}{|c|c|c|c|c|c|c|c|c|}
\hline $\begin{array}{l}\text { Inter- } \\
\text { arrival }\end{array}$ & WIP & $\begin{array}{c}\text { Thr. } \\
\text { Time } 1\end{array}$ & $\begin{array}{c}\text { Thr. } \\
\text { Time } 2\end{array}$ & $\begin{array}{c}\text { Thr. } \\
\text { Time } 3\end{array}$ & $\begin{array}{l}\text { Average } \\
\text { Thr. time }\end{array}$ & Tardiness & Thr. & $\begin{array}{c}\text { Av. } \\
\text { utilization }\end{array}$ \\
\hline \multicolumn{9}{|c|}{ Cellular manufacturing system } \\
\hline 4.5 & 19.350 & 79.250 & 79.150 & 118.560 & 87.160 & 339000 & 13.294 & 0.880 \\
\hline 5 & 12.800 & 60.040 & 59.840 & 80.040 & 64.000 & 128000 & 11.980 & 0.790 \\
\hline 6 & 8.690 & 49.890 & 50.130 & 60.320 & 52.090 & 42335 & 10.010 & 0.660 \\
\hline 7 & 6.820 & 46.570 & 46.630 & 53.158 & 47.920 & 20479 & 8.530 & 0.566 \\
\hline \multicolumn{9}{|c|}{ Local approach } \\
\hline 4.5 & 19.580 & 92.080 & 91.770 & 72.970 & 88.160 & 333000 & 13.300 & 0.916 \\
\hline 5 & 12.60 & 64.070 & 64.150 & 58.250 & 62.940 & 108000 & 11.990 & 0.827 \\
\hline 6 & 8.700 & 52.770 & 52.810 & 50.610 & 52.350 & 36006 & 9.960 & 0.686 \\
\hline 7 & 6.990 & 49.400 & 49.580 & 47.990 & 49.190 & 19339 & 8.520 & 0.592 \\
\hline \multicolumn{9}{|c|}{ Global approach } \\
\hline 4.5 & 21.400 & 101.260 & 101.170 & 77.170 & 96.430 & 411000 & 13.280 & 0.914 \\
\hline 5 & 14.120 & 72.950 & 72.590 & 61.800 & 70.580 & 170000 & 11.980 & 0.828 \\
\hline 6 & 9.920 & 61.030 & 61.470 & 53.040 & 59.610 & 81686 & $\begin{array}{l}9.980 \\
\end{array}$ & 0.692 \\
\hline 7 & 7.980 & 57.610 & 57.430 & 49.700 & 55.960 & 54160 & 8.550 & 0.596 \\
\hline \multicolumn{9}{|c|}{ Global approach exclusive } \\
\hline 4.5 & 20.621 & 96.850 & 96.980 & 76.340 & 92.830 & 376000 & 13.290 & 0.915 \\
\hline 5 & 13.270 & 68.100 & 67.910 & 60.070 & 66.430 & 134000 & 11.970 & 0.822 \\
\hline 6 & 9.290 & 56.730 & 56.810 & 51.960 & 55.810 & 55324 & 9.980 & 0.684 \\
\hline 7 & 7.440 & 53.020 & 53.060 & 49.020 & 52.250 & 33884 & 8.540 & 0.588 \\
\hline
\end{tabular}

Table A1. Numerical results - Static environment without machine breakdowns

\begin{tabular}{|c|c|c|c|c|c|c|c|c|}
\hline $\begin{array}{c}\text { Inter- } \\
\text { arrival }\end{array}$ & WIP & $\begin{array}{c}\text { Thr. } \\
\text { Time } 1\end{array}$ & $\begin{array}{c}\text { Thr. } \\
\text { Time } 2\end{array}$ & $\begin{array}{c}\text { Thr. } \\
\text { Time } 3\end{array}$ & $\begin{array}{l}\text { Average } \\
\text { Thr. time }\end{array}$ & tardiness & Thr. & $\begin{array}{c}\text { Av. } \\
\text { utilization }\end{array}$ \\
\hline \multicolumn{9}{|c|}{ Cellular manufacturing system } \\
\hline 4.5 & 26.000 & 108.790 & 110.910 & 144.650 & 116.980 & 609000 & 13.300 & 0.880 \\
\hline 5 & 15.100 & 72.300 & 72.300 & 88.340 & 75.570 & 213000 & 11.970 & 0.790 \\
\hline 6 & 9.440 & 54.950 & 55.100 & 63.100 & 56.660 & 66439 & 9.990 & 0.660 \\
\hline 7 & 7.280 & 49.700 & 49.850 & 55.430 & 50.910 & 32775 & 8.570 & 0.570 \\
\hline \multicolumn{9}{|c|}{ Local approach } \\
\hline 4.5 & 26.158 & 124.640 & 125.040 & 88.550 & 117.620 & 604000 & 13.290 & 0.915 \\
\hline 5 & 14.120 & 72.670 & 72.700 & 62.900 & 70.730 & 165000 & 11.970 & 0.824 \\
\hline 6 & 9.210 & 55.980 & 56.150 & 52.470 & 55.350 & 51813 & 9.980 & 0.692 \\
\hline 7 & 7.270 & 51.370 & 51.440 & 48.940 & 50.910 & 26673 & 8.560 & 0.592 \\
\hline \multicolumn{9}{|c|}{ Global approach } \\
\hline 4.5 & 28.290 & 135.750 & 135.930 & 93.170 & 127.330 & 697000 & 13.280 & 0.913 \\
\hline 5 & 15.960 & 83.280 & 82.940 & 67.030 & 79.900 & 242000 & 11.960 & 0.823 \\
\hline 6 & 10.430 & 64.630 & 64.860 & 54.800 & 62.760 & 99858 & 9.960 & 0.690 \\
\hline 7 & 8.330 & 59.920 & 60.240 & 51.100 & 58.290 & 65920 & 8.560 & 0.596 \\
\hline \multicolumn{9}{|c|}{ Global approach exclusive } \\
\hline 4.5 & 27.540 & 131.590 & 131.800 & 92.48 & 123.890 & 664000 & 13.290 & 0.912 \\
\hline 5 & 15.132 & 78.100 & 78.230 & 65.65 & 75.680 & 205000 & 11.980 & 0.824 \\
\hline 6 & 9.890 & 60.700 & 60.710 & 54.04 & 59.380 & 75866 & 9.980 & 0.684 \\
\hline 7 & 7.730 & 55.330 & 55.440 & 50.07 & 54.330 & 43396 & 8.530 & 0.584 \\
\hline
\end{tabular}

Table A2. Numerical results - Static environment 


\begin{tabular}{|c|c|c|c|c|c|c|c|c|}
\hline $\begin{array}{c}\text { Inter- } \\
\text { arrival }\end{array}$ & WIP & $\begin{array}{c}\text { Thr. } \\
\text { Time } 1\end{array}$ & $\begin{array}{c}\text { Thr. } \\
\text { Time } 2\end{array}$ & $\begin{array}{c}\text { Thr. } \\
\text { Time } 3\end{array}$ & $\begin{array}{l}\text { Average } \\
\text { Thr. time }\end{array}$ & tardiness & Thr. & $\begin{array}{c}\text { Av. } \\
\text { utilization }\end{array}$ \\
\hline \multicolumn{9}{|c|}{ Cellular manufacturing system } \\
\hline 4.5 & 29.750 & 123.450 & 124.840 & 168.680 & 133.760 & 769000 & 13.290 & 0.880 \\
\hline 5 & 15.660 & 74.220 & 74.440 & 93.480 & 78.330 & 237000 & 11.980 & 0.790 \\
\hline 6 & 9.530 & 55.230 & 55.420 & 64.230 & 57.160 & 69743 & 9.990 & 0.662 \\
\hline 7 & 7.320 & 50.130 & 49.970 & 55.650 & 51.190 & 34091 & 8.570 & 0.570 \\
\hline \multicolumn{9}{|c|}{ Local approach } \\
\hline 4.5 & 26.590 & 126.990 & 127.120 & 89.930 & 119.720 & 624000 & 13.280 & 0.910 \\
\hline 5 & 14.300 & 73.490 & 73.700 & 63.180 & 71.540 & 172000 & 11.980 & 0.824 \\
\hline 6 & 9.180 & 55.900 & 55.980 & 52.350 & 55.240 & 51233 & 9.970 & 0.689 \\
\hline 7 & 7.200 & 51.460 & 51.240 & 48.750 & 50.840 & 26054 & 8.490 & 0.590 \\
\hline \multicolumn{9}{|c|}{ Global approach } \\
\hline 4.5 & 20.840 & 98.280 & 97.990 & 76.410 & 93.870 & 386000 & 13.290 & 0.916 \\
\hline 5 & 13.370 & 68.430 & 68.820 & 60.320 & 67.000 & 139000 & 11.960 & 0.820 \\
\hline 6 & 9.310 & 57.020 & 56.920 & 51.960 & 56.000 & 56732 & 9.960 & 0.684 \\
\hline 7 & 7.460 & 53.040 & 53.240 & 49.020 & 52.330 & 34375 & 8.550 & 0.583 \\
\hline \multicolumn{9}{|c|}{ Global approach exclusive } \\
\hline 4.5 & 20.830 & 98.100 & 98.000 & 76.230 & 93.780 & 385000 & 13.300 & 0.916 \\
\hline 5 & 13.260 & 68.330 & 67.710 & 60.040 & 66.460 & 134000 & 11.950 & 0.822 \\
\hline 6 & 9.290 & 56.730 & 56.790 & 52.090 & 55.840 & 55651 & 9.980 & 0.684 \\
\hline 7 & 7.470 & 53.120 & 53.050 & 49.140 & 52.310 & 34345 & 8.570 & 0.587 \\
\hline
\end{tabular}

Table A3. Numerical results - Mix changes (stage length: 8640 )

\begin{tabular}{|c|c|c|c|c|c|c|c|c|}
\hline $\begin{array}{c}\text { Inter- } \\
\text { arrival }\end{array}$ & WIP & $\begin{array}{c}\text { Thr. } \\
\text { Time } 1\end{array}$ & $\begin{array}{c}\text { Thr. } \\
\text { Time } 2\end{array}$ & $\begin{array}{c}\text { Thr. } \\
\text { Time } 3\end{array}$ & $\begin{array}{l}\text { Average } \\
\text { Thr. time }\end{array}$ & tardiness & Thr. & $\begin{array}{c}\text { Av. } \\
\text { utilization }\end{array}$ \\
\hline \multicolumn{9}{|c|}{ Cellular manufacturing system } \\
\hline 4.5 & 28.713 & 120.480 & 120.660 & 161.370 & 129.150 & 725000 & 13.290 & 0.880 \\
\hline 5 & 15.610 & 73.680 & 73.940 & 94.410 & 78.040 & 234000 & 11.980 & 0.792 \\
\hline 6 & 9.4700 & 55.230 & 55.310 & 63.860 & 57.030 & 68844 & 9.960 & 0.660 \\
\hline 7 & 7.2900 & 49.810 & 50.060 & 55.690 & 51.110 & 33848 & 8.550 & 0.569 \\
\hline \multicolumn{9}{|c|}{ Local approach } \\
\hline 4.5 & 26.640 & 127.250 & 127.430 & 89.450 & 119.840 & 625000 & 13.290 & 0.913 \\
\hline 5 & 14.290 & 73.690 & 73.620 & 62.720 & 71.500 & 171000 & 11.970 & 0.823 \\
\hline 6 & 9.2100 & 55.880 & 56.250 & 52.460 & 55.350 & 51827 & 9.970 & 0.690 \\
\hline 7 & 7.2500 & 51.210 & 51.420 & 49.020 & 50.860 & 26573 & 8.540 & 0.592 \\
\hline \multicolumn{9}{|c|}{ Global approach } \\
\hline 4.5 & 20.900 & 98.520 & 98.300 & 76.410 & 94.070 & 388000 & 13.300 & 0.916 \\
\hline 5 & 13.400 & 68.730 & 68.930 & 60.210 & 67.130 & 140000 & 11.960 & 0.820 \\
\hline 6 & 9.300 & 56.920 & 56.640 & 52.180 & 55.870 & 56155 & 9.980 & 0.686 \\
\hline 7 & 7.470 & 53.110 & 53.340 & 48.920 & 52.380 & 34736 & 8.550 & 0.583 \\
\hline \multicolumn{9}{|c|}{ Global approach exclusive } \\
\hline 4.5 & 21.020 & 98.780 & 98.720 & 77.380 & 94.520 & 393000 & 13.310 & 0.916 \\
\hline 5 & 13.310 & 68.080 & 68.380 & 60.450 & 66.690 & 136000 & 11.960 & 0.822 \\
\hline 6 & 9.300 & 56.860 & 56.840 & 52.060 & 55.910 & 56135 & 9.970 & 0.684 \\
\hline 7 & 7.440 & 53.070 & 53.150 & 48.930 & 52.290 & 34081 & 8.530 & 0.584 \\
\hline
\end{tabular}

Table A4. Numerical results - Mix changes (stage length: 4320) 


\begin{tabular}{|c|c|c|c|c|c|c|c|c|}
\hline $\begin{array}{c}\text { Inter- } \\
\text { arrival }\end{array}$ & WIP & $\begin{array}{c}\text { Thr. } \\
\text { Time } 1\end{array}$ & $\begin{array}{c}\text { Thr. } \\
\text { Time } 2\end{array}$ & $\begin{array}{c}\text { Thr. } \\
\text { Time } 3\end{array}$ & $\begin{array}{l}\text { Average } \\
\text { Thr. time }\end{array}$ & tardiness & Thr. & $\begin{array}{c}\text { Av. } \\
\text { utilization }\end{array}$ \\
\hline \multicolumn{9}{|c|}{ Cellular manufacturing system } \\
\hline 4.5 & 28.130 & 118.970 & 119.020 & 155.050 & 126.510 & 699000 & 13.290 & 0.880 \\
\hline 5 & 15.550 & 73.690 & 75.250 & 90.820 & 77.820 & 232000 & 11.970 & 0.794 \\
\hline 6 & 9.500 & 55.580 & 55.220 & 63.600 & 57.070 & 68734 & 9.980 & 0.660 \\
\hline 7 & 7.300 & 49.830 & 50.010 & 56.120 & 51.180 & 34309 & 8.550 & 0.566 \\
\hline \multicolumn{9}{|c|}{ Local approach } \\
\hline 4.5 & 26.630 & 127.210 & 127.470 & 89.460 & 119.820 & 625000 & 13.290 & 0.913 \\
\hline 5 & 14.280 & 73.420 & 73.810 & 63.010 & 71.510 & 171000 & 11.970 & 0.823 \\
\hline 6 & 9.240 & 56.190 & 56.220 & 52.410 & 55.450 & 52426 & 9.980 & 0.692 \\
\hline 7 & 7.250 & 51.300 & 51.470 & 49.070 & 50.920 & 26794 & 8.540 & 0.592 \\
\hline \multicolumn{9}{|c|}{ Global approach } \\
\hline 4.5 & 20.870 & 98.370 & 98.290 & 76.400 & 93.980 & 388000 & 13.290 & 0.916 \\
\hline 5 & 13.430 & 68.770 & 69.140 & 60.340 & 67.250 & 141000 & 11.970 & 0.822 \\
\hline 6 & 9.320 & 56.890 & 57.240 & 52.060 & 56.080 & 57341 & 9.970 & 0.684 \\
\hline 7 & 7.460 & 53.220 & 52.930 & 49.010 & 52.280 & 34236 & 8.550 & 0.586 \\
\hline \multicolumn{9}{|c|}{ Global approach exclusive } \\
\hline 4.5 & 20.760 & 97.710 & 97.580 & 76.720 & 93.500 & 383000 & 13.290 & 0.916 \\
\hline 5 & 13.280 & 68.270 & 68.040 & 60.370 & 66.610 & 136000 & 11.950 & 0.820 \\
\hline 6 & 9.290 & 56.840 & 56.870 & 52.140 & 55.920 & 56172 & 9.960 & 0.684 \\
\hline 7 & 7.460 & 53.010 & 53.100 & 49.100 & 52.270 & 34139 & 8.560 & 0.588 \\
\hline
\end{tabular}

Table A5. Numerical results - Mix changes (stage length: 2880 )

\begin{tabular}{|c|c|c|c|c|c|c|c|c|}
\hline $\begin{array}{c}\text { Inter- } \\
\text { arrival }\end{array}$ & WIP & $\begin{array}{c}\text { Thr. } \\
\text { Time } 1\end{array}$ & $\begin{array}{c}\text { Thr. } \\
\text { Time } 2\end{array}$ & $\begin{array}{c}\text { Thr. } \\
\text { Time } 3\end{array}$ & $\begin{array}{l}\text { Average } \\
\text { Thr. time }\end{array}$ & tardiness & Thr. & $\begin{array}{c}\text { Av. } \\
\text { utilization }\end{array}$ \\
\hline \multicolumn{9}{|c|}{ Cellular manufacturing system } \\
\hline 4.5 & 27.680 & 117.170 & 117.420 & 152.450 & 124.590 & 681000 & 13.290 & 0.880 \\
\hline 5 & 15.250 & 73.110 & 73.590 & 88.390 & 76.430 & 220000 & 11.950 & 0.790 \\
\hline 6 & 9.500 & 55.200 & 55.390 & 64.140 & 57.100 & 69468 & 9.970 & 0.660 \\
\hline 7 & 7.270 & 49.790 & 49.810 & 55.460 & 50.950 & 33092 & 8.550 & 0.567 \\
\hline \multicolumn{9}{|c|}{ Local approach } \\
\hline 4.5 & 26.490 & 126.660 & 126.300 & 89.760 & 119.180 & 619000 & 13.290 & 0.913 \\
\hline 5 & 14.300 & 73.360 & 73.760 & 62.980 & 71.460 & 171000 & 11.980 & 0.827 \\
\hline 6 & 9.170 & 55.870 & 56.130 & 52.280 & 55.260 & 51358 & 9.940 & 0.688 \\
\hline 7 & 7.240 & 51.180 & 51.450 & 48.870 & 50.830 & 26352 & 8.540 & 0.592 \\
\hline \multicolumn{9}{|c|}{ Global approach } \\
\hline 4.5 & 20.700 & 97.400 & 97.480 & 76.500 & 93.280 & 381000 & 13.280 & 0.916 \\
\hline 5 & 13.380 & 68.670 & 68.630 & 60.200 & 66.980 & 139000 & 11.970 & 0.823 \\
\hline 6 & 9.310 & 57.010 & 56.880 & 52.110 & 55.990 & 56678 & 9.970 & 0.684 \\
\hline 7 & 7.440 & 52.840 & 53.170 & 48.920 & 52.190 & 33801 & 8.550 & 0.586 \\
\hline \multicolumn{9}{|c|}{ Global approach exclusive } \\
\hline 4.5 & 20.560 & 96.500 & 96.700 & 76.420 & 92.600 & 374000 & 13.290 & 0.916 \\
\hline 5 & 13.320 & 68.330 & 68.160 & 60.100 & 66.630 & 136000 & 11.980 & 0.822 \\
\hline 6 & 9.330 & 57.070 & 57.000 & 52.070 & 56.060 & 56864 & 9.980 & 0.686 \\
\hline 7 & 7.470 & 53.270 & 53.150 & 48.950 & 52.370 & 34494 & 8.550 & 0.586 \\
\hline
\end{tabular}

Table A6. Numerical results - Mix changes (stage length: 2160) 


\begin{tabular}{ccccccccc}
\hline $\begin{array}{c}\text { Stage } \\
\text { Length }\end{array}$ & WIP & $\begin{array}{c}\text { Thr. } \\
\text { Time 1 }\end{array}$ & $\begin{array}{c}\text { Thr. } \\
\text { Time 2 }\end{array}$ & $\begin{array}{c}\text { Thr. } \\
\text { Time 3 }\end{array}$ & $\begin{array}{c}\text { Average } \\
\text { Thr. time }\end{array}$ & tardiness & Thr. & $\begin{array}{c}\text { Av. } \\
\text { utilization }\end{array}$ \\
\hline \multicolumn{7}{c}{ Cellular manufacturing system } \\
\hline 8640 & 11.710 & 62.000 & 62.050 & 73.100 & 64.270 & 120000 & 10.910 & 0.720 \\
\hline 4320 & 11.710 & 61.830 & 62.100 & 73.300 & 64.270 & 120000 & 10.910 & 0.720 \\
\hline 2880 & 11.740 & 61.870 & 62.100 & 73.790 & 64.370 & 121000 & 10.920 & 0.723 \\
\hline 2160 & 11.720 & 61.860 & 62.110 & 73.090 & 64.230 & 120000 & 10.930 & 0.720 \\
\hline \multicolumn{7}{c}{ Local approach } \\
\hline 8640 & 11.250 & 62.890 & 62.870 & 56.550 & 61.620 & 94149 & 10.930 & 0.754 \\
\hline 4320 & 11.170 & 62.580 & 62.690 & 56.290 & 61.380 & 92256 & 10.900 & 0.754 \\
\hline 2880 & 11.180 & 62.580 & 62.710 & 56.430 & 61.410 & 92398 & 10.910 & 0.754 \\
\hline 2160 & 11.210 & 62.760 & 62.810 & 56.400 & 61.520 & 92984 & 10.920 & 0.754 \\
\hline \multicolumn{7}{c}{ Global approach } \\
\hline 8640 & 10.970 & 61.440 & 61.370 & 55.250 & 60.180 & 85759 & 10.920 & 0.748 \\
\hline 4320 & 11.010 & 61.460 & 61.440 & 55.440 & 60.250 & 86338 & 10.950 & 0.750 \\
\hline 2880 & 11.060 & 61.600 & 61.810 & 55.450 & 60.460 & 87777 & 10.970 & 0.753 \\
\hline 2160 & 10.860 & 61.110 & 61.220 & 55.030 & 59.950 & 83760 & 10.860 & 0.750 \\
\hline \multicolumn{7}{c}{ Global approach exclusive } \\
\hline 8640 & 11.010 & 61.390 & 61.520 & 55.590 & 60.290 & 86458 & 10.940 & 0.750 \\
\hline 4320 & 10.970 & 61.310 & 61.480 & 55.390 & 60.210 & 85675 & 10.920 & 0.748 \\
\hline 2880 & 10.940 & 61.230 & 61.400 & 55.430 & 60.150 & 85101 & 10.900 & 0.748 \\
\hline 2160 & 10.950 & 61.290 & 61.340 & 55.380 & 60.140 & 85009 & 10.910 & 0.748 \\
\hline
\end{tabular}

Table A7. Numerical results - interarrival changes

\begin{tabular}{|c|c|c|c|c|c|c|c|c|}
\hline $\begin{array}{c}\text { Stage } \\
\text { Length }\end{array}$ & WIP & $\begin{array}{c}\text { Thr. } \\
\text { Time } 1\end{array}$ & $\begin{array}{c}\text { Thr. } \\
\text { Time } 2 \\
\end{array}$ & $\begin{array}{c}\text { Thr. } \\
\text { Time } 3 \\
\end{array}$ & $\begin{array}{c}\text { Average } \\
\text { Thr. time }\end{array}$ & tardiness & Thr. & $\begin{array}{c}\text { Av. } \\
\text { utilization }\end{array}$ \\
\hline \multicolumn{9}{|c|}{ Cellular manufacturing system } \\
\hline 8640 & 11.920 & 62.910 & 63.060 & 74.330 & 65.330 & 128000 & 10.920 & 0.724 \\
\hline 4320 & 11.990 & 63.140 & 63.290 & 75.180 & 65.670 & 130000 & 10.940 & 0.723 \\
\hline 2880 & 11.900 & 62.500 & 62.710 & 75.150 & 65.170 & 127000 & 10.940 & 0.725 \\
\hline 2160 & 11.920 & 62.600 & 63.090 & 74.810 & 65.290 & 127000 & 10.940 & 0.722 \\
\hline \multicolumn{9}{|c|}{ Local approach } \\
\hline 8640 & 11.290 & 63.020 & 63.100 & 56.790 & 61.830 & 95598 & 10.940 & 0.740 \\
\hline 4320 & 11.270 & 63.040 & 63.170 & 56.620 & 61.830 & 95425 & 10.920 & 0.754 \\
\hline 2880 & 11.170 & 62.680 & 62.620 & 56.570 & 61.440 & 92676 & 10.890 & 0.754 \\
\hline 2160 & 11.250 & 62.860 & 62.990 & 56.630 & 61.680 & 94243 & 10.930 & 0.754 \\
\hline \multicolumn{9}{|c|}{ Global approach } \\
\hline 8640 & 10.920 & 61.510 & 61.480 & 55.180 & 60.250 & 86315 & 10.850 & 0.748 \\
\hline 4320 & 10.970 & 61.610 & 61.470 & 55.320 & 60.310 & 86632 & 10.900 & 0.748 \\
\hline 2880 & 11.050 & 62.120 & 61.860 & 55.370 & 60.690 & 89043 & 10.910 & 0.753 \\
\hline 2160 & 11.060 & 61.820 & 61.860 & 55.600 & 60.600 & 88684 & 10.940 & 0.750 \\
\hline \multicolumn{9}{|c|}{ Global approach exclusive } \\
\hline 8640 & 10.970 & 61.500 & 61.480 & 55.360 & 60.280 & 86289 & 10.900 & 0.750 \\
\hline 4320 & 11.060 & 61.790 & 61.630 & 55.620 & 60.500 & 88044 & 10.950 & 0.752 \\
\hline 2880 & 11.010 & 61.620 & 61.610 & 55.630 & 60.430 & 87314 & 10.910 & 0.748 \\
\hline 2160 & 11.080 & 61.940 & 61.890 & 55.650 & 60.670 & 88933 & 10.940 & 0.749 \\
\hline
\end{tabular}

Table A8. Numerical results - interarrival and mix changes 